\title{
CHOLINESTERASE PADA DARAH PETANI PENYEMPROT PESTISIDA DI DESA LOKA KABUPATEN BANTAENG
}

\author{
Effendy Rasiyanto ${ }^{1)}$, Muh. Rifo Rianto ${ }^{1)}$, Farida Hidayati ${ }^{1)}$ \\ ${ }^{1)}$ Akademi Analis Kesehatan Muhammadiyah Makassar \\ Alamat Korespondensi: babatjatim@gmail.com
}

\begin{abstract}
Abstrak
Enzim Cholinesterase adalah suatu bentuk dari kata lisbiologik yang didalam jaringan tubuh berperan untuk menjaga agar otot-otot, kelenjar-kelenjar dan sel-sel syaraf bekerja secara terorganisir dan harmonis. Enzim Cholinesterase dapat terganggu oleh pemakain pestisida secara berlebihan dan juga tidak menggunakan alat pelindung diri.Penelitian ini bertujuan untuk mengetahui gambaran hasil Cholinesterase pada petani penyemprot pestisida di Desa Loka Kabupaten bantaeng. Objek dalam penelitian ini adalah 5 serum petani dan di periksa di Balai Besar Labolatorium Kesehatan dengan metode fotometri. Hasil penelitian ini menunjukan bahwa petani di Desa Loka Kabupaten Bantaeng tidak terpapar pestisida dilihat dari hasil pemeriksaan Cholinesterase yang normal, gambaran hasil yang didapatkan adalah7857-9177 U/L dengan nilai normal 4620-11500 U/L. Setelah dilakukan pemeriksaan penelitian ini dapat disimpulkan bahwa petani di Desa Loka Kabupaten Bantaeng tidak terpapar dengan pestisida.
\end{abstract}

Kata Kunci: Cholinesterase, Pestisida, Petani

\section{PENDAHULUAN}

Pestisida adalah bahan kimia yang banyak di gunakan dalam bidang pertanian. Pemakain pestisida banyak di gunakan oleh petani sayur yaitu untuk memberantas hama sehingga mendapatkan hasil yang memuaskan namun pemakaian pestisida sangatlah berbahaya apabila tidak sesuai dengan standar keamanan karena dapat menimbulkan keracunan dan menyebabkan kematian.

Dalam bidang pertanian banyak digunakan senyawa kimia, antara lain sebagai pupuk tanaman dan pestisida. Pestisida merupakan zat kimia yang dipakai untuk mengendalikan atau membasmi hama. Pestisida merupakan racun, tetapi memiliki tujuan khusus yaitu untuk melindungi hasil pertanian dari organisme lain, yaitu hama. Jumlah senyawa kimia yang digunakan sebagai pestisida kurang lebih 900 macam dengan tidak kurang dari 45.000 formulasi. Di Indonesia, terdaftar dan diizinkan beredar kurang lebih 500 macam formulasi, 13 diantaranya dari golongan pestisida terbatas atau relatif sangat berbahaya (Joseph, 2013).

Penggunaan pestisida dapat menimbulkan keracunan, baik bersifat akut maupun kronis, keracunan akut dapat menimbulkan beberapa efek diantaranya yaitu sakit kepala, pusing, kudis, sakit dada, mual, muntah-muntah, sakit otot, keringat berlebih, kram, diare, sulit bernapas, pandangan kabur dan kematian. Keracunan akut di ukur berdasarkan nilai dosis letal (LD-50).

Penggunaan pestisida yang tidak sesuai dengan standar keamanan dapat menimbulkan keracunan pada petani. Prosedur penggunaan pestisida yang aman akan mengurangi terjadinya keracunan akibat pestisida. Pestisida dapat masuk kedalam tubuh lewat inhalasi sehingga untuk mengetahui tingkat keracunan pestisida dalam tubuh diperlukan pemeriksaan kadar cholinesterase pada darah petani sayur (Joseph, 2013). Cholinesterase adalah enzim, suatu bentuk dari katalis biologik yang didalam jaringan tubuh berperan untuk menjaga agar otot-otot, kelenjar-kelenjar dan sel- 
sel syaraf bekerja secara terorganisir dan harmonis. Ketika pestisida penghambat Cholinesterase memasuki tubuh manusia atau binatang, pestisida ini menempel pada enzym Cholinesterase tidak dapat memecahkan Acetycholinesterase menjadi Cholinesterase dan asam asetat. Pemecahan Asetylcholine ini di perlukan untuk menghentikan penyampaian rangsangan syaraf (Tampudu, 2010).

Permenakes No.Per-03/Men/1986 pasal 2 ayat $2 \mathrm{a}$ menyebutkan untuk menjaga efek yang tidak diinginkan, maka dianjurkan supaya tidak melebihi empat jam per hari dalam seminggu berturutturut bila menggunakan pestisida. WHO (1996) menetapkan lama penyemprotan terpanjang pestisida saat bekerja selama 5-6 jam per hari dan setiap minggu harus dilakukan pengujian kesehatan, termasuk kadar cholinesterase dalam darah (Budiawan, 2013).

Berdasarkan penelitian yang dilakukan oleh Organisasi Pangan Dunia, 1992 yang meneliti 214 orang petani selama 2 tahun, terjadinya keracunan akut yang diderita oleh petani responden disebabkan petani tidak memahami bahaya pestisida terhadap kesehatannya. Disamping itu petani juga tidak menggunakan pelindung yang aman sehingga para petani harus menerima keadaan sakit sebagai resiko bekerja di sektor pertanian (Tampudu, 2010).

Berdasarkan hasil observasi peneliti

Desa Loka Kabupaten Bantaeng adalah desa yang memiliki penduduk yang dominan bermata pencaharian petani sayur, sebagian besar petani tersebut menggunakan pestisida gelongan organofosfat dan karbamat untuk memberantas hama pada sayuransayurannya, namun petani tersebut seringkali menggunakan pestisida tanpa menggunakan penutup mulut (masker), sarungtangan atau alat pelindung diri lainnya sehingga besar kemungkinan petani tersebut terpapar pestisida dan mengakibatkan keracuna atau penuruna enzim Cholinesterasen.
Pestisida masuk ke dalam tubuh dapat melalui saluran pernapasan, kulit, dan mulut sehingga apabilah berkerja petani dengan pestisida dalam jangka waktu panjang dan tidak menggunakan alat pelindung diri maka akan berdampak bagi kesehatannya yaitu penurunan enzim Cholinesterase atau keracunan akut maupun kronis.

Petani di Desa Loka Kabupaten Bantaeng memiliki lahan yang luas untuk bertani dan menggunakan pestisida sebagai pemberantas hama untuk tanaman sayurannya sehingga peneliti tertarik untuk melakukan penelitian dengan judul gambaran hasil Cholinesterase pada petani penyemprot pestisida Desa Loka Kabupaten Bantaeng.

\section{METODOLOGI PENELITIAN}

Alat dan Bahan

Alat yang di gunakan pada penelitian ini adalah fotometer 5010, spoid, tourniquet, kapas alkohol $70 \%$, tabung reaksi, sentrifuge, mikropipet 1000 $\mu$, mikropipet $20 \mu$,mikropipet $5 \mu$, blue tip, white tip, tissue.

Bahan yang di gunakan adalah reagen A (pyrophosphate $95 \mathrm{mmol} / \mathrm{L}$, hexacyanoferrate (III) $2,5 \mathrm{mmol} / \mathrm{L} \mathrm{pH}$ 7,6) dan Reagen B (butyrylthiocholine 60 $\mathrm{mmol} / \mathrm{L}$ ).

\section{Prosedur Penelitian}

Pengolahan sampel

Sampel darah vena di biarkan membeku terlebih dahulu pada suhu kamr selama 20-30 menit, kemudian sentrifuge 3000 rpm selam 5-15 menit. Pemeriksaan serum dilakukan dalam waktu jam setelah pengambilan sampel. Serum yang memiliki syarat harus tidak kelihatan merah (lisis) dan keruh (lipemik).

\section{Pemeriksaan kadar cholinesterase}

Metode yang di gunakan pada pemeriksaan enzim cholinesterase adalah metode fotometrik. Cholinesterase (CHE) mengkatalisis hidrolisis dan butiriltocolin menjadi tiokolin menjadi asam butirik. Konsentrasi tiokolin dan asam butirik di tentukan dari pengukuran jumlah 
Heksasianoferat (III) pada panjang gelombang $405 \mathrm{~nm}$.

\section{Analisa Data}

Analisa data yang digunakan dalam penelitian ini adalah bersifat deskriptif yaitu untuk mengetahui gambaran hasil cholisnesterase terhadap petani yang terpapar pestisida.

\section{HASIL DAN PEMBAHASAN}

Berdasarkan hasil penelitian yang telah dilaksanakan terhadap 5 sampel petani penyemprot pestisida di Desa Loka Kabuapaten Bantaeng diperoleh hasil sebagai berikut :

Tabel 1. Tabel Hasil Pemeriksaan Cholinesterase

\begin{tabular}{|c|c|c|c|}
\hline $\begin{array}{l}\text { Kode } \\
\text { Sampel }\end{array}$ & $\begin{array}{l}\text { Hasil } \\
\text { (U/L) }\end{array}$ & $\begin{array}{l}\text { Nilai } \\
\text { Normal } \\
\text { (U/L) }\end{array}$ & Keterangan \\
\hline 1 & 9177 & $\begin{array}{l}4620- \\
11500\end{array}$ & Negative \\
\hline 2 & 8332 & $\begin{array}{l}4620- \\
11500\end{array}$ & Negative \\
\hline 3 & 7899 & $\begin{array}{l}4620- \\
11500\end{array}$ & Negative \\
\hline 4 & 7857 & $\begin{array}{l}4620- \\
11500\end{array}$ & Negative \\
\hline 5 & 7680 & $\begin{array}{l}4620- \\
11500\end{array}$ & Negative \\
\hline
\end{tabular}

Cholinesterase adalah suatu enzim, bentuk dari katalis biologik, yang didalam jaringan tubuh berperan untuk menjaga agar otot-otot, kelenjar-kelenjar, dan selsel saraf bekerja secara terorganisir dan harmonis. Jika aktifitas Cholinesterase turun secara drastis maka akan timbul gejala berupa kejang-kejang, tremor yang di ikuti dengan kehilangan kesadaran.

Dalam penelitian gambaran hasil Cholinesterase pada petani penyemprot pestisida di Desa Loka Kabupaten Bantaeng, jumlah sampel sebanyak 5 orang dengan pengambilan sampel sesuai kriteria yang telah di tentukan seperti: tidak menggunakan alat pelindung diri (APD), masa kerja minimal 4 tahun dan menggunakan pestisida golongan organofosfat atau karbamat.

Pengambilan sampel dilakukan sesuai prosedur peneliti, dengan metode fotometri dan pemeriksaan tersebut di lakukan di Balai Besar Labolatorium Kesehatan Makassar, dan dari hasil pemeriksaan tersebut di dapatkan hasil pada sampel 1 dengan nilai 9177, sampel ke 2 dengan nilai 8332, sampel ke 3 dengan nilai 7899 , sampel 4 dengan nilai 7857, dan sampel 5 dengan nilai 7680 . Nilai normal pada enzim Cholinesterase adalah 4620-11500 U/L, sehingga dari hasil pemeriksaan ke 5 sampel tersebut dinyatakan belum terpapar pestisida atau normal.

Faktor yang dapat mempengaruhi kadar Cholinesterase adalah penggunaan alat pelindung diri (APD). Dari hasil penelitian yang telah dilakukan 5 sampel tersebut tidak menggunakan alat pelindung diri. Penggunaan APD secara lengkap mempunyai pengaruh secara bermakna terhadap kadar Cholinesterase darah responden. Salah satu faktor yang sering di lupakan petani, apalagi jika ada kelainan pada kulit dan atau bersama keringat, penyerapan pestisida melalui kulit akan lebih efektif. Keracunan karena partikel pestisida atau butiran semprot terhisap melalui hidung merupakan kasus terbanyak nomor dua setelah kontaminasi kulit, tangan, pernafasan dan mata.

Petani Desa Loka Kabupaten Bantaeng adalah petani yang tidak menggunakan alat penlindung diri (APD) ketika melakukan penyemprotan pada tanaman atau ketika berkontaminasi dengan pestisida, dan menjadi sampel pada penelitian ini.

Faktor lain yang mempengaruhi adalah lama tiap kali penyemprotan. Lama penyemprotan adalah lama waktu yang di gunakan untuk menyemprot tanaman menggunakan pestisida organofosfat dalam satuan jam setiap harinya. Jika lama penyemprotan petani masih dalam batas aman 1-3 jam maka kerajunan akibat pestisida bisa di minimalisir. Gejala keracunan pestisida bisa timbul apabilah lebih dari 4 jam kontak, tetapi bisa timbul setelah 12 jam. Lama petani kontak dengan pestisida maka akan semakin besar kemungkinan 
petani mengalami keracunan apalagi jika diiringi dengan waktu penyemprotan.

Ditinjau dari lama paparan terhadap pestisida gelongan organofosfat dan karbamat tiap kali penyemprotan tanaman atau sayuran petani di Desa Loka Kabupaten Bantaeng melakukan peyemprotan pestisida 1 jam dalam waktu 1 bulan tiap tahunnya sehingga pemakain pestisida di Desa tersebut masi batas aman.

Petani di Desa Loka Kabupaten Bantaeng sering kali mendapatkan penyuluhan tentang resiko pemakain pestisida Sehingga petani tersebut menggunakan pestisida dengan berhatihati.

Untuk keracunan ringan dengan istirahat minimal 1 minggu dapat meningkatkan enzim Cholinesterase menjadi normal, sedangkan untuk keracunan yang sedang memerlukan waktu istirahat yang lebih lama untuk mencapai aktivitas Cholinesterase normal.

\section{KESIMPULAN}

Pada penelitian tentang gambaran hasil Cholinesterase pada petani penyemprot pestisida di Desa Loka Kabupaten Bantaeng dengan besaran sampel sebanyak 5 orang petani Dan di dapatkan hasil 7857-9177 U/L dengan nilai normal 4620-11500 U/L dan berdasarkan hasil Cholinesterase tersebut dapat di simpulkan bahwa petani penyemprot pestisida di Desa Loka Kabupaten Bantaeng tidak terpapar dengan pestisida.

\section{SARAN}

1. Bagi masyarakat atau petani hendaknya ketika melakukan penyemprotan agar menggunakan APD agar terhindar dari faktor resiko.

2. Bagi mahasiswa analis kesehatan, penelitian ini dapat menjadi sebagai masukan untuk penelitian selanjutnya yang lebih yang mendalam dengan sampel yang lebih banyak.
3. Pemakain pestisida ketika melakukan penyemprotan sebisa mungkin kurang dari 4 jam dalam 1 hari.

\section{DAFTAR PUSTAKA}

Balai Besar Labolatorium Kesehatan. 2013. Pedoman Umum. Makassar: Balai Pustaka.

Budiawan, A.R. 2013. Faktor Resiko Cholinesterase Rendah Pada Petani Bawang Merah (Skripsi). Semarang: Universitas Negeri Semarang.

Connel, D.W., dan Miller G.J. 2006. Kimia dan Ekotoksikologi Pencemaran. Jakarta: Universitas Indonesia (UI-Press).

Joseph, W.B.S., et all. 2013. Hubungan Antara Masa Kerja, Pengelolaan Pestisida Dan Lama Penyemprotan Dengan Kadar Cholinesterase Darah Petani Sayur Di Kecematan Rurukan Satu Kota Tomohon. (Skripsi). Manado: Universitas Sam Ratulangi.

Kee, J.L. 2013. Pedoman Pemeriksaan Labolatorium dan Diagnostik. Jakarta: Penerbit Buku Kedokteran EGC.

Lu, F.C. 1995. Toksikologi Dasar. Jakarta: Universitas Indonesia (UIPrees).

Sukmawati, E.D. 2000. Hubungan Karasteristik dan Praktek Pengelolaan Pestisida Petani Penyemprot Hama Dengan Tingkat Keracunan Pestisida. Available From: https://core.ac.uk/download/ pdf 11709135.pdf

Tampudu, S., et all. 2010. Gambaran Hasil Cholineterase Darah Petani Penyemprot Pestisida Di Desa Minasa Baji Kabupaten Maros. Available From: http://download.portalgaruda.org/ar ticle.php? article $=165780 \& v a l=6044 \&$ title

Widman, F.K. 1995. Tinjauan Klinis Atas Hasil Pemeriksaan Labolatorium. Jakarta: Penerbit Buku Kedokteran EGC. 